then on his life was so bound up with anthropology as almost to be an epitome of the progress of the science in Great Britain. He was appointed University lecturer in ethnology, becoming reader in 1909 and retaining this post until his retirement in 1926. He was also lecturer in ethnology (Martin White Benefaction) in the University of London during 1904-9. He was president of the Royal Anthropological Institute during 1901-1902, its Huxley Memorial Medallist in 1920, and its first Rivers Medallist in 1924. He was a constant attendant at the meetings of the British Association, presiding over Section $\mathrm{H}$ in 1902 (Belfast) and 1905 (South Africa); he was also president of the Folk-lore Society, and of the Cambridge Antiquarian Society. In company with his daughter, now Mrs. Rishbeth, he re-visited Australia and New Guinea in 1914, collecting some fresh material for the "Reports" and greatly increasing his knowledge of Papuasian canoes, knowledge which later led to the publication, with James Hornell, of "Canoes of Oceania".

On his retirement from the Cambridge readership in 1926, he retained his post of honorary curator of the New Guinea collections, which he arranged and catalogued, intending later to do the same for the Borneo material. Leisure from teaching, and intensified contact with museum material, led to the planning of a new work largely concerned with decorative art. This required much museum research - especially in Holland, where he was enthusiastically received-and the MS. of "Smoking and Tobacco Pipes in New Guinea" was completed only a week before his death.

Haddon reviewed for several papers; he was a contributor to Nature for sixty years, and was the author of countless memoirs and papers, as well as an unusual number of important volumes. This is no place to discuss the Torres Straits "Reports", which he edited and so largely wrote; they speak for themselves. Of his other works, "Iban or Sea Dyak Fabries and their Patterns" (1936), written in conjunction with L. E. Start, again indicates his persistent interest in decorative art. "Races of Man" (1909, 1924 editions), and "The Wanderings of Peoples" (1911), both illustrate the influence of his zoological training, while the latter book is an exhibition of the extremely condensed style he could at need employ. "We Europeans", written in collaboration with Julian Huxley, is an example of the best form of cuvre de vulgarization, produced in the hope of countering some of the insane theories of race now prevailing.

It is surpassingly difficult to give any idea of Haddon the man in a short notice such as this. His strength of build, prominent features, and later his shock of snow-white hair, made him a conspicuous figure in any assembly. Intensely energetic, he had a great capacity for work (in Torres Straits he worked a longer day than any of us), and accuracy of detail seemed to come naturally to him. While the outstanding feature of his character was a broad humanity and kindliness, there was a somewhat unexpected streak of Puritanism, which, however, mellowed greatly as time went on, his wife persuading him to smoke and even to take a drink now and then. He had a keen sense of humour, could be frivolous, and thoroughly enjoyed a holiday as a rest, but in the main his thought and conversation were directed and constructive, and apart from his work he had no hobbies. He was working for an hour or two a day until within a couple of weeks of his death. Far more disinterested than most, there was no one whom he would not go out of his way to help, provided that the claimant was himself doing his best. He hated pretence, and 'side' withered in his presence.

Haddon's work shows a capacity for wide generalizations with, as it seems, a preference for the intensive study of smaller areas in which the intrinsic characters of a people can be compared and contrasted with foreign traits. His method and capacity in this direction are particularly well shown in much of volume $]$ (the last written) of the "Reports". It was no doubt his kindliness, tolerance, and honesty of purpose that enabled him to make friends with natives and to gain their confidence in the way he did. "He close up alongside God, he savvy too much" ("too much", that is, a great deal), was the phrase used of him by a Murray Islander, and indeed probably expresses the opinion of all his friends. To have known, appreciated, and been the pupil of A. C. Haddon has been one of my greatest privileges. C. G. Seligman.

\section{W. R. King}

Mr. W. R. King, who died on April 8, aged seventytwo, was Wimshurst's assistant in the development of the Wimshurst electrical 'influence' machine, which of course displaced the frictional machine for the generation of static electricity in the laboratory. This type of apparatus seems to have required quite special skill in the selection and application of apparently simple materials, such as suitable glass and varnishes, necessary for reliability for experiments in static electricity ; and Mr. King's experience in this respect was exceptional. The old Nairn machine of Sir Humphry Davy, now standing in the hall of the Royal Institution, owes its restoration to his skill, and he has also carried out similar work for the Science Museum.

In the early days of electrical knowledge numerous and ingenious working models were used to illustrate the behaviour of charged bodies. Many of these were quaint but very striking; Mr. King's collection was unique, and at one of the Friday Evening Exhibitions at the Royal Institution especially, when he showed many of them in action, he easily kept the members interested and delighted to a late hour. He also distinguished himself at the Faraday Exhibition at the Albert Hall in 1931 by a very striking continuous display of lightning from a battery of Leyden jars charged by his largest power machine.

Mr. King's strength had been ebbing for two or three years, continually weakened by bronchial attacks; but he died quietly in his workshop chair. W. J. G. 